DOI: $10.19195 / 0137-1134.109 .10$

\title{
ZASADY I REGUŁY. PEWNOŚĆ PRAWA PODATKOWEGO A ŚLEPA ULICA KONKRETU*
}

Celem tego artykułu jest poddanie dyskusji i krytyce modelu legislacyjnego przyjętego przy tworzeniu prawa podatkowego. Model ten opiera się na strategii nadawania tekstowi prawnemu maksymalnej dostępnej precyzji (ścisłości) przez budowanie szczegółowych reguł prawnych. Jest to w konsekwencji także krytyka sposobu konstruowania treści prawa podatkowego: treść ta wywodzi się bowiem z brzmienia tekstu prawnego i paradygmatu wykładni. Z kazuistyczną formą tekstu prawnego sprzężony jest tekstualizm - stanowisko preferujące dyrektywy (argumenty) wykładni językowej ${ }^{1}$.

$\mathrm{W}$ artykule postuluję przyjęcie odmiennego modelu, zakładającego oparcie prawa na zasadach, a nie tylko regułach prawnych, oraz posługiwanie się w tekście prawnym wyrażeniami otwartymi ( $w$ tym zwrotami niedookreślonymi). Wbrew obiegowej opinii taka technika nie niszczy pewności prawa; przeciwnie, tworzy dobre warunki do jej urzeczywistniania.

\section{KRYTYKA JAKOŚCI LEGISLACYJNEJ PRAWA PODATKOWEGO}

Niska jakość legislacyjna przepisów prawa podatkowego i wynikające z niej zagrożenia dla pewności prawa są przedmiotem stałej — i nieco już zrytualizo-

* Praca powstała w wyniku realizacji projektu badawczego nr 2014/15/D/HS5/01599 pt. Racjonalność prawa. Unikanie opodatkowania jako problem wyktadni i stanowienia prawa finansowanego ze środków Narodowego Centrum Nauki.

${ }^{1}$ Nie omawiam różnych postaci tej preferencji; w tej sprawie zob. T. Spyra, Granice wykladni prawa. Znaczenie językowe tekstu prawnego jako granica wyktadni, Warszawa 2006. 
wanej - krytyki ${ }^{2}$. Skomplikowane, zmienne (niestabilne) ${ }^{3}$, dotknięte wadami legislacyjnymi (zatomizowane i kazuistyczne), a także obszerne (składające się z dużej, i wciąż rosnącej, liczby przepisów) ${ }^{4}$ prawo podatkowe jest ,prawem tajemniczym”5 czy też „kauczukowym, ciemnym”. Zastrzeżenia tej treści formułowane pod adresem prawa podatkowego nie są specyficzne dla prawa polskiego ani dla prawa współczesnego ${ }^{7}$.

Communis opinio polskiej doktryny prawa podatkowego jest również teza, że prawo podatkowe ma charakter ingerencyjny, ponieważ ogranicza prawo własności (a za jego pośrednictwem wolność) ${ }^{8}$, oraz że pewność prawa (jego przewidywalność dla adresatów przepisów - podatników) ma w obrębie tej gałęzi szczególną wagę — stąd jej wymagany standard jest podwyższony9 ${ }^{9}$ Niedostateczna komunikatywność (jasność) przepisów tej gałęzi prawa jest szczególnie dolegliwa, bo pozbawia pewności prawa w obszarze, w którym jest ona wartością szczególnie cenną.

2 Spośród wielu publikacji można wymienić przykładowo: B. Brzeziński, W. Nykiel, Legislacja podatkowa, [w:] Prawo podatkowe. Teoria. Instytucje. Funkcjonowanie, red. B. Brzeziński, Torun 2009, s. 147-157; A. Mariański, Rozstrzyganie watpliwości na korzyść podatnika. Zasada prawa podatkowego, Warszawa 2009, s. 21; A. Gomułowicz, Aspekt prawotwórczy sadownictwa administracyjnego, Warszawa 2008, s. 50-51; J. Małecki, Lex falsa lex non est, [w:] Ex iniuria non oritur ius. Księga pamiątkowa ku czci Wojciecha Ląckowskiego, red. A. Gomułowicz, J. Małecki, Poznań 2003, s. 60; Kontrola tworzenia i stosowania prawa podatkowego pod rzadami Konstytucji RP, red. E. Ruśkowski, Warszawa 2006, zwłaszcza s. 132-133; J. Glumińska-Pawlic, Zasada pewności opodatkowania w polskim prawie podatkowym, [w:] Zasady prawa. Materiały konferencyjne, red. C. Martysz, A. Matan, Z. Tobor, Bydgoszcz 2007, passim. Zob. też pismo Rzecznik Praw Obywatelskich I. Lipowicz do Przewodniczącego Komisji Kodyfikacyjnej Ogólnego Prawa Podatkowego L. Etela z dnia 21 stycznia 2015 r., https://www.rpo.gov.pl/sites/default/files/Do\%20 Komisji\%20Kodyfikacyjnej\%20Og\%C3\%B3lnego\%20Prawa\%20Podatkowego\%20ws.\%20reformy\%20systemu\%20podatkowego.pdf.

${ }^{3}$ Dla przykładu, ustawa z dnia 26 lipca 1991 r. o podatku dochodowym od osób fizycznych (tekst jedn. Dz.U. 2012 poz. 361 ze zm.) od publikacji ostatniego tekstu jednolitego przed czterema laty została znowelizowana 39 razy.

${ }^{4}$ Por. np. B. Brzeziński, O idei uproszczenia prawa podatkowego, [w:] Konstytucja, ustrój, system finansowy państwa. Księga pamiątkowa ku czci prof. Natalii Gajl, red. T. Dębowska-Romanowska, A. Jankiewicz, Warszawa 1999, s. 333-344. Polskie prawo podatkowe objętością nie dorównuje prawu wielu innych państw, ale dotyka je ta sama tendencja do rozrostu.

5 B. Kunicka-Michalska, Podstawowe wady naszego prawa, [w:] Jakość prawa, red. A. Wasilkowski, Warszawa 1996, s. 161. Zob. też wyrok TK z dnia 5 marca 2003 r., sygn. akt K 7/01.

6 S. Rozmaryn, Prawo podatkowe a prawo prywatne w świetle wyktadni prawa, Lwów 1939, s. 187.

7 Por. surowe oceny prawa brytyjskiego formułowane dziesiątki lat temu, omówione w: J.A. Jones, Tax Law: Rules or Principles, „Fiscal Studies” 17, 1996, nr 3, s. 63.

8 Zob. H. Filipczyk, Ingerencyjny charakter prawa podatkowego - jedna teza, dwie interpretacje, [w:] XXV lat przeobrażeń w prawie finansowym i prawie podatkowym - ocena dokonań i wnioski na przyszłość, red. Z. Ofiarski, Szczecin 2014, s. 399-409 i powołana tam literatura.

9 Takie jest również stanowisko Trybunału Konstytucyjnego, zob. np. wyroki z dnia 27 listopada 2007 r., SK 39/06; z dnia 14 lipca 2004 r., SK 16/02 i in. 
Odpowiedzią polskiego ustawodawcy na te i inne deficyty przepisów podatkowych jest podążanie wciąż tą samą drogą: dalsze stanowienie prawa w dążeniu do nadania mu możliwe największej określoności i ścisłości (precyzji). Jest to tytułowa „ślepa ulica konkretu”. Strategia ta jest nieskuteczna, ponieważ precyzja tekstu prawnego jest przeciwstawna jego komunikatywności: im jest on bardziej precyzyjny: szczegółowy, konkretny, napisany językiem technicznym, tym mniej komunikatywny dla odbiorcy ${ }^{10}$.

Doktryna prawa podatkowego ma stosunek ambiwalentny do typowo przyjmowanej techniki legislacji podatkowej. Z jednej strony dostrzegane są jej mankamenty, a nadmiar kazuistyki i związana z nim inflacja przepisów - krytykowane ${ }^{11}$, z drugiej jednak wskazuje się, że „kazuistyka i wysoki stopień skomplikowania przepisów podatkowych mniej szkodzą realizacji praw podatnika niż ich niedookreśloność"12. Kazuistyka postrzegana jest więc często jako cena, którą należy zapłacić za ochronę prawowitych interesów podatnika (w tym zwłaszcza interesu, jaki ma on w tym, by prawo było przewidywalne), a droga legislacyjnego konkretu - jako jedyne możliwe rozwiązanie ${ }^{13}$.

\section{PRZYCZYNY I RACJE STOSOWANEJ TECHNIKI LEGISLACYJNEJ}

Dlaczego w prawie podatkowym przyjęto „model prawodawczego konkretu”? Są trzy możliwe, niekonkurencyjne wobec siebie, wyjaśnienia tego faktu.

Po pierwsze, krytykowany stan rzeczy można wyjaśniać przez wskazanie na zbiór przyczyn faktycznych, powodujących, że strategii legislacyjnej — jeżeli rozumieć przez nią świadomą i celową orientację oraz organizację zespołu działań - w odniesieniu do prawa podatkowego właściwie nie ma. W konsekwencji postać tekstu prawnego stanowi niezamierzony rezultat niedostatków procesu legislacyjnego — braków w zakresie polityki podatkowej, doraźności „akcyjności” legislacji, niedostatecznej refleksji nad ekonomicznymi aspektami opodatkowania, niedostatecznych kwalifikacji urzędników redagujących przepisy i parlamentarzystów je uchwalających, wielorakich wad organizacji procesu legislacyjnego itd.

10 Por. S. Wronkowska, Postulat jasności prawa i niektóre metody jego realizacji, „Państwo i Prawo" 1976, nr 10, s. 24-25.

11 Zob. np. A. Gomułowicz, Podatki a etyka, Warszawa 2013, s. 77; P. Borszowski, Elastyczność a zmiany prawa podatkowego, [w:] XXV lat przeobrażeń w prawie finansowym i prawie podatkowym - ocena dokonań i wnioski na przyszłość, red. Z. Ofiarski, Szczecin 2014, s. 379-387.

12 P. Karwat, Eliminacja ,zlych nawyków” w stanowieniu i stosowaniu prawa podatkowego a ochrona praw podatnika, „Prawo i Podatki” 2008, nr 4 (wydanie specjalne), s. 13-15.

13 Zgłaszane są też kompromisowe propozycje przyjęcia modelu mieszanego, odnalezienia via media między kazuistyką a ogólnością — zob. B. Brzeziński, op. cit., s. 335-337. 
Wyjaśnienie to, choć w znacznej mierze trafne, jest z pewnością niekompletne. Wydaje się, że dominujący styl redagowania przepisów podatkowych nie jest tylko efektem ubocznym nieefektywności procesów i nieudolności zaangażowanych w nie osób ${ }^{14}$.

Po drugie, za postać przepisów prawa podatkowego ma odpowiadać charakterystyka normowanej dziedziny oraz relacji, w jakiej dziedzina ta pozostaje do regulacji prawnej. W ramach tej kategorii wyjaśnień wskazuje się m.in., że normowana materia jest złożona i ulega dynamicznym zmianom, ponieważ takie właśnie jest życie gospodarcze, a także że ze względu na przedmiot regulacji budulcem norm prawa podatkowego są również przepisy prawa konstytucyjnego ${ }^{15}$, handlowego i cywilnego. Jednocześnie na to prawo składa się regulacja należąca do kilku poziomów normatywnych: ustalenie treści norm prawnych wymaga wzięcia pod uwagę przepisów prawa krajowego, prawa Unii Europejskiej, międzynarodowego prawa podatkowego (do którego należą zwłaszcza umowy o unikaniu podwójnego opodatkowania oraz umowy o wymianie informacji podatkowych).

Jakkolwiek obserwacje te same w sobie są trafne, to jednak nie jest jasne, jak okoliczności, na które wskazują, przekładają się na konieczność stosowania „modelu legislacji konkretu”.

W tej grupie przyczyn mieści się jednak również zjawisko tzw. ektopii podatku dochodowego (J. Prebble), tj. dyslokacji, przemieszczenia, oderwania podatku dochodowego jako instytucji prawnej od jego przedmiotu ${ }^{16}$. Polega ono na rozdźwięku między prawem podatkowym a regulowaną przez nie dziedziną. Dochód jako gospodarcze zjawisko jest ujmowany w kategorię normatywną w drodze jego istotnej konwencjonalizacji. W konsekwencji opodatkowaniu podatkiem dochodowym podlega konstrukt normatywny, a nie rzeczywiste zjawisko występujące w świecie. »Dochód « jest »sztucznym konstruktem«. »Dochód«, to znaczy zyski z działalności gospodarczej dla potrzeb podatkowych, nie jest czymś, co spotykane w naturze" 17 .

14 Tym bardziej że zjawisko „słabej kondycji ustawodawstwa” dotyczy nie tylko prawa podatkowego; por. np. S. Wronkowska, Polski proces prawotwórczy - między autonomiq a polityka, „Ius et Lex” 2005, nr 3 (1), s. 193-211; K.H. Goetz, R. Zubek, Stanowienie prawa w Polsce: reguty legislacyjne a jakość ustawodawstwa, „Ius et Lex” 2005, nr 3 (1), s. 237-258.

15 Nie oznacza to, że przepisy Konstytucji (w tym jej art. 84 i 217) są przepisami prawa podatkowego.

16 Zob. m.in. J. Prebble, Why is tax law incomprehensible, „British Tax Revue” 1994, nr 4, s. 380-393; idem, Asomatous Income, Institute for Taxation and Business Law, Conference Paper Four Annual New Zealand - Pacific Tax and Business Law Conference, Tonga 1995; idem, Ectopia, tax law, and international taxation, „British Tax Review” 1997, nr 5, s. 383-403; idem, Ectopia, the Root Cause of the Ineliminable Fictions of Income Tax Law, Working Paper, Western Regional Council of the Institute of Chartered Accountants of India, Mumbai 30 November 2006 i in. Zob. też H. Filipczyk, Refleksje o przedmiocie podatku dochodowego, „Kwartalnik Prawa Podatkowego” 2015, nr 2, s. 39-55.

17 J. Prebble, Should tax legislation be written from a principle and purpose point of view or a precise and detailed point of view?, „British Tax Review” 1998, nr 2, s. 114. 
„Ektopiczny” charakter podatku dochodowego zobowiązuje do namysłu nad możliwością regulacji opodatkowania tym podatkiem w sposób ogólny — niekazuistyczny. Skoro jednak jest to zjawisko ograniczone do podatku dochodowego, stanowi ono niewystarczające wyjaśnienie fenomenu przyjętej w prawie podatkowym techniki legislacyjnej. Technika ta bowiem stosowana jest nie tylko w wypadku ustaw o podatkach dochodowych. Przykładowo, mimo że przedmiotem opodatkowania podatkiem od towarów i usług jest dostawa (towaru lub usługi), a prawne jej pojęcie odzwierciedla byt rzeczywisty, rzeczywiste zdarzenie gospodarcze (nie powstaje tu problem ektopii), także ustawa z dnia 11 marca $2004 \mathrm{r}$. o podatku od towarów i usług ${ }^{18}$ skażona jest kazuistyką ${ }^{19}$.

Po trzecie, kazuistyczna technika legislacji jest inspirowana kulturą prawną — przekonaniami, które należą do tej kultury. Dotyczą one w szczególności wspomnianego ingerencyjnego charakteru prawa podatkowego oraz konstytucyjnej zasady ustawowej regulacji opodatkowania (art. 84 i 217 Konstytucji RP). Ten charakter oraz konstytucyjne zakotwiczenie praw i obowiązków podatników wymagają, jak się uważa, nadawania tekstowi prawnemu maksymalnej określoności — konkretyzacji przy pomocy szczegółowych reguł prawnych.

$\mathrm{W}$ mariażu z tym stylem redakcyjnym pozostaje preferencja dla wykładni językowej. Im węższe ramy, w jakich może poruszać się interpretator, tym większa potrzeba precyzacji przepisów prawa - po to, by zakresem tych przepisów (wywodzonych z nich norm) zostały objęte zamierzone przez ustawodawcę stany faktyczne i aby ze stanami tymi zostały związane pożądane przez niego skutki podatkowe (aby zapewnić regulacji tzw. adekwatność).

\section{PRAWO PODATKOWE A PRAWO KARNE}

Zaskakuje, a zarazem narzuca się z nieodpartą siłą, obserwacja odmienności technik legislacyjnych stosowanych w prawie podatkowym oraz prawie karnym. Prawo karne - będące prawem ingerencyjnym par excellence — bynajmniej nie operuje kazuistyką. W kodeksie karnym ${ }^{20}$ obficie występują wyrażenia mające charakter wyrażeń znaczeniowo otwartych, zwrotów niedookreślonych lub klauzul generalnych, np. ,inny podobnie niebezpieczny przedmiot” (art. 159; art. 223 $\S 1$; art. $280 \S 2$; art. $345 \S 3$ ), ,czynności związane bezpośrednio z zapewnieniem bezpieczeństwa ruchu pojazdów mechanicznych” (art. 180), „osoba nieporadna”

18 Tekst jedn. Dz.U. 2011 Nr 177, poz. 1054 ze zm.

19 Skądinąd taka jest też właściwość prawa UE w tym obszarze — podstawowy akt prawny na szczeblu Unii, tj. dyrektywa Rady 2006/112/WE z dnia 28 listopada 2006 r. w sprawie wspólnego systemu podatku od wartości dodanej (Dz.Urz. UE L 347 z 11.12.2006 r., s. 1), jest obszerny, złożony i szczegółowy.

20 Ustawa z dnia 6 czerwca 1997 r. — Kodeks karny (Dz.U. Nr 88, poz. 553 ze zm.). 
(art. $207 \S 1$; art. $210 \S 1$; art. 211), ,znikoma szkodliwość społeczna czynu” (art. 1 $\S 2$; art. 45a) itd.

Wyrzeczenie się dążenia do nadania tekstowi prawnemu maksymalnej ścisłości per se nie przeszkadza w tym, by w praktyce stosowania przepisy prawa karnego uzyskały uchwytną treść 21 .

Wynika stąd, że nawet przyjmując niezwykle (i moim zdaniem — zbyt) daleko idące założenie, iż prawo podatkowe jest w tym samym sensie i stopniu ingerencyjne co prawo karne ${ }^{22}$, cecha ingerencyjności nie stoi — jak się okazuje — na przeszkodzie stosowaniu techniki legislacji ogólnej. Dlatego wskazane wcześniej przyczyny przyjętej w prawie podatkowym techniki legislacyjnej, związane z przekonaniami należącymi do kultury prawnej, są jej przyczynami (wyjaśniają ją), ale nie jej racjami (nie mogą jej uzasadniać).

\section{REGUŁY I ZASADY}

Redakcja przepisów podatkowych jest obiektem łatwej, może zbyt łatwej i sztampowej, krytyki. Jaki jest „,pozytywny program” — uzasadniona alternatywa wobec dotychczasowego stylu, zbliżająca przepisy prawa podatkowego choćby do przepisów prawa karnego?

Prawo podatkowe - procesowe i materialne — powinno być zbudowane z zasad i reguł prawnych (a nie tylko z samych reguł). Powinno mieć postać dwupoziomową — ze statusem wyróżnionym zasad jako nadrzędnych nad regułami prawnymi.

Pojęcie zasady prawnej jest wieloznaczne. Przez zasadę prawną rozumiem w tym wypadku normę prawną 23 określającą podstawowe elementy i cechy konstrukcyjne podatku (względnie procedury podatkowej). W wypadku ustaw podatkowego prawa materialnego zasady prawa powinny określać w szczególności przedmiot opodatkowania i cel ustawy oraz determinować, a jednocześnie artykułować

21 Warto dodać, że zarówno w wypadku prawa karnego, jak i prawa podatkowego gwarantem praw obywatela jest sąd — odpowiednio sąd karny i sąd administracyjny (ten ostatni — jako sprawujący sądową kontrolę nad zgodnością z prawem działań organów podatkowych).

22 Orędownikiem tej tezy (a także jej domniemanych konsekwencji) jest A. Mariański, por. np. „Normy prawa podatkowego, podobnie jak normy prawa karnego, silnie ingerują w sferę wolności człowieka. Ze względu na podobny charakter prawa ingerencyjnego, dogmatyka prawa podatkowego jest nastawiona na ochronę i gwarantowanie praw obywatela w stosunku do państwa. Oznacza to, że zakres ingerencji musi być wyraźnie określony. Powoduje to zwiększenie wymagań stawianych przepisom prawa podatkowego, które winny charakteryzować się wyjątkową precyzją. Ma to również znaczenie w procesie dokonywania wykładni prawa" (idem, op. cit., LEX).

${ }^{23}$ Chodzi zatem o zasadę prawa w sensie dyrektywalnym (zob. S. Wronkowska, M. Zieliński, Z. Ziembiński, Zasady prawa. Zagadnienia podstawowe, Warszawa 1974, s. 28 n.) i w znaczeniu ścisłym (ibidem, s. 53 n.). 
tzw. strukturę głęboką normowanego ustawą podatku ${ }^{24}$. „Zasady prawa” to zatem w tym wypadku ,zasady konstrukcyjne” opodatkowania danym podatkiem.

Zasady prawa na tle reguł prawnych cechują się szczególną doniosłością, a przez to wyróżnioną pozycją w procesie wykładni i stosowania prawa. Regułom prawnym (a zatem dyrektywom - normom prawnym innym niż zasady) należy nadawać treść zgodną z zasadami prawa. To stanowi najważniejszy wymiar nadrzędności zasad nad regułami. Nadrzędność ta ma zatem charakter hierarchiczny (reguła prawna nie może być niezgodna z zasadą; w razie prima facie kolizji między nimi przeważa zasada) ${ }^{25}$.

Zasady prawne zarówno w części określającej hipotezę normy prawnej, jak i w części określającej jej dyspozycję są wyrażone w sposób bardziej ogólny niż reguły.

Ustanowienie zasad i dwupoziomowość regulacji, składającej się z zasad i reguł, pozwoli na bardziej skromną — zwięźlejszą i prostszą — redakcję reguł prawnych. Wobec obowiązywania zasad wyznaczających podstawową strukturę opodatkowania danym podatkiem reguły prawne będą mogły zawierać zwroty niedookreślone (otwarte), a ustawodawca będzie mógł wyrzec się aspiracji do zapewnienia kompletności regulacji na ich poziomie. Ewentualne luki prawne na poziomie reguł będą mogły bowiem zostać usunięte przez normy prawne ustanowione na szczeblu zasad lub za ich pomocą — przez rozumowanie na nich oparte (także z zastosowaniem analogii: ,kierunek”-,,wektor” rozumowania per analogiam wyznaczą zasady) ${ }^{26}$. Usuwanie luk będzie przy tym dokonywane ad casum, $\mathrm{w}$ warunkach, na tle i na potrzeby rozstrzygnięcia konkretnej rozpatrywanej właśnie sprawy.

Realizacja tej propozycji powinna zatem doprowadzić do uproszczenia prawa podatkowego ${ }^{27}$.

${ }^{24}$ Nie jest tak, że z każdą taką zasadą prawa sprzężona jest odrębna wartość (jak w ujęciu prezentowanym w: M. Kordela, Zasady prawa. Studium teoretycznoprawne, Poznań 2012; A. Peczenik, Non-positivist conception of law, [w:] Teoria prawa. Filozofia prawa. Współczesne prawo i prawoznawstwo, Torun 1998, s. 223-248) — zasady materialnego prawa podatkowego nie nakazują (zakazują) realizacji określonej wartości, nie mają więc same przez się wymiaru aksjologicznego. Na uboczu pozostawiam też koncepcję R. Dworkina i podział logiczny dyrektyw na „reguły” i „zasady” prawne jako dyrektywy niekonkluzywne (niedefinitywne, prima facie) — zob. idem, Biorac prawa poważnie, Warszawa 1998, rozdział II.

25 Należy zakładać, że zasady i reguły byłyby ujęte w akcie prawnym tego samego rzędu. Dla ustanowienia hierarchicznej nadrzędności zasad nad regułami wymagane byłoby zawarcie $w$ tym akcie stosownej reguły kolizyjnej.

${ }^{26}$ Zdaję sobie sprawę, że propozycja stosowania analogii, bez dalszej kwalifikacji, tj. także na niekorzyść podatnika, odbiega od poglądów przyjętych w doktrynie prawa podatkowego.

27 Idea uproszczenia prawa podatkowego ma swoją obszerną literaturę, doczekała się również mniej lub bardziej zaawansowanych prób urzeczywistnienia (m.in. w Australii, USA, Nowej Zelandii, Wielkiej Brytanii). W Polsce postulat takiego uproszczenia jest również zgłaszany często, choć wyraża się również sceptycyzm co do szans powodzenia takiego projektu (zob. np. B. Brzeziński, Uproszczenie podatków i prawa podatkowego, [w:] Prawo podatkowe. Teoria..., s. 209). 


\section{DOKTRYNA ANGLOSASKA}

Zarówno wskazany problem, jak i jego proponowane rozwiązanie mają swoje odpowiedniki w doktrynie anglosaskiej, w szczególności w jej ustaleniach dotyczących podatku dochodowego.

Diagnoza postaci legislacyjnej przepisów podatkowych jest tam równie surowa co w Polsce. John Avery Jones pisze o ,pladze szaleństwa reguł podatkowych" 28 i ,spirali legislacji”"29. Jak przestroga brzmi spostrzeżenie, że

chociaż objętość sama w sobie nie stanowi miary złożoności, to gdy mamy do czynienia z ustawodawstwem w zakresie podatku dochodowego przekraczającym 6000 stron, myślę, że nadszedł czas, by zahamować spiralę i pomyśleć chociaż o spowolnieniu tempa wzrostu. Jeżeli pragnie się uleczyć szaleństwo reguł podatkowych, trzeba uczynić coś więcej niż tylko leczyć symptomy ${ }^{30}$.

Dlatego liczni autorzy - m.in. J.A. Jones, J. Braithwaite i J. Freedman ${ }^{31}-$ postulują, by zrąb regulacji podatkowej wyznaczyły zasady prawa. W porównaniu z regułami prawnymi zasady prawne mają charakteryzować się większą ogólnością oraz większą doniosłością. Doniosłość ta pojmowana jest rozmaicie jako dająca zasadom prymat nad regułami w razie kolizji między nimi lub nie. W tym ostatnim wypadku zasady rozumiane są jako uogólnienia zespołu reguł, ich pozbawione przymiotu normatywności objaśnienia (zwłaszcza przez wskazanie „przedmiotu i celu” regulacji lub oczekiwanego społeczno-gospodarczego rezultatu ich stosowania) lub jako ogólne standardy, które ukierunkowują wykładnię reguł i które mają być spełnione (zrealizowane) w maksymalnym stopniu, jaki jest osiągalny ze względu na treść reguł ${ }^{32}$.

28 J.A. Jones, op. cit., s. 88.

29 Ibidem, s. 69.

30 Ibidem.

31 Zob. J.A. Jones, op. cit., s. 63-89; J. Braithwaite, Making Law More Certain: A Theory, Centre for Tax System Integrity Research School of Social Sciences Australian National University Canberra, Working Paper No 44, December 2002; J. Freedman, Improving (not perfecting) tax legislation: Rules and principles revisited, „British Tax Review” 2010, $\mathrm{nr} 6$, s. 717-736. Zob. też D.A. Weisbach, Formalism in the tax law, „University of Chicago Law Review” 1999, nr 66, s. 860-886; D. McBarnet, C. Whelan, The elusive spirit of the law: Formalism and the struggle for legal control, „Modern Law Review” 54, 1991, nr 6, s. 848-873; R. Krever, Plain English drafting, purposive drafting, principle-based drafting: Does any of it matter, [w:] Beyond Boundaries. Developing Approaches to Tax Avoidance and Tax Risk Management, red. J. Freedman, Oxford Centre for Business Taxation 2008, s. 189-196; S. Picciotto, Constructing compliance: Gameplaying, tax law and the regulatory state, „Law \& Policy” 29, 2007, nr 1, s. 11-30.

32 Różnorodność koncepcji i związaną z nią niejednoznaczność pojęcia „opartego na zasadach" stylu redagowania przepisów odnotowuje m.in. G. Cooper (idem, Legislating principles as a remedy for tax complexity, „British Tax Review” 2010, nr 4, s. 341-342). Podobny dylemat odnośnie do stosunku zasad do reguł rozpoznano też w doktrynie polskiej. 
Dopracowaną i godną uwagi koncepcję legislacji podatkowej opartej na zasadach i regułach przedstawił J. Braithwaite ${ }^{33}$. Streszcza się ona w następujących postulatach:

— ustanowienia zasad prawnych o charakterze normatywnym (wiążących dla podatników) $)^{34}$;

— ustanowienia reguł prawnych w szczególnie złożonych obszarach danej dziedziny normowanej prawem podatkowym;

— ustanowienia reguł prawnych w celu określenia skutków podatkowych transakcji często występujących w obrocie gospodarczym ${ }^{35}$; nymi ${ }^{36}$.

— przyznania zasadom prawnym prymatu w razie kolizji z regułami praw-

W tej koncepcji zasada prawna nie służy jedynie objaśnianiu treści reguł prawnych i pokonywaniu wątpliwości interpretacyjnych co do tej treści. Sama w sobie stanowi pełnoprawną — podlegającą bezpośredniemu zastosowaniu dyrektywę postępowania. Zasady są tu zatem normami prawnymi, i to hierarchicznie wyższymi od reguł prawnych (przeważają nad regułami w razie konfliktu). Zespoły reguł prawnych ustanowione dla transakcji typowych stanowią egzemplifikację treści i sposobu działania zasad; powinno im towarzyszyć (jak należy rozumieć ujęte w uzasadnieniu ustawy podatkowej) wyjaśnienie, jak mają się do zasad ${ }^{37}$.

Propozycję Braithwaite'a, w której punkt ciężkości regulacji podatkowoprawnej spoczywa w zasadach, a nie regułach prawnych, uważam za trafną.

\section{TEKST PRAWNY I WYKŁADNIA}

Z dotychczasową strategią i techniką legislacji podatkowej idzie w parze preferencja dla wykładni językowej. Sposób stanowienia przepisów jest ściśle związany z panującym paradygmatem wykładni. Związek ten wynika z faktu, iż obie pochodzą z tego samego „pnia ideowego” - wskazanych wcześniej przekonań związanych z ingerencyjnością prawa podatkowego. Przybiera on jednak także

33 J. Braithwaite, op. cit. Autor ten uważa, że prawo podatkowe potrzebuje połączenia zasad i reguł bardziej niż inne obszary prawa.

34 Odpowiadając na pytanie, czym zasady różnią się od reguł, Braithwaite powtarza za Josephem Razem, że „rules prescribe relatively specific acts; principles prescribe highly unspecific actions" (ibidem, s. 2).

35 „Tax laws can be written by setting down binding principles, of which one is the GAAR, then detailed rules to illustrate how the principles should be applied to common concrete commercial arrangements [...]. If there are 1000 rare ways of setting up the kinds of arrangements covered by the law, but only a dozen are used with any frequency, then these are the 12 concrete arrangements that should be fleshed out into rules" (ibidem, s. 11-12).

\footnotetext{
36 Ibidem, s. 2-4.
}

37 Ibidem. 
postać mechanizmu sprzężenia zwrotnego. Im większa kazuistyka, „,rozproszenie” i uszczegółowienie reguł prawnych, tym większa tendencja do ich wykładania w sposób ścisły - językowy. W mnogości złożonych przepisów gubi się bowiem ogólny sens ustawy i jej podstawowe założenia. Z drugiej jednak strony, im więcej literalizmu w wykładni, a mniej prób dopatrzenia się w gąszczu przepisów organizujących je norm nadrzędnych (ucieleśniających wewnętrzną racjonalność ustawy), tym większa potrzeba ustanawiania nowych reguł prawnych celem wyrażenia idei ustawodawcy. Doskonałość legislacyjna, w pogoń za którą wybierają się w ten sposób twórcy prawa, jest jednak nieosiągalna jak wciąż oddalający się horyzont ${ }^{38}$.

Jak trafnie zwraca uwagę J.A. Jones, przez kazuistyczną technikę prawotwórczą wyraża się brak zaufania do sądów — do ich zdolności urzeczywistnienia zasad ogólnych, na których oparta jest ustawa podatkowa — i wola maksymalnego dostępnego związania ich działań przy pomocy „litery prawa”. Z drugiej strony, to samoograniczenie narzucane sobie przez autorytatywnych interpretatorów przepisów, w tym sądy, wywołuje niekończącą się potrzebę mnożenia reguł. Spostrzeżenie tej zależności nie jest zresztą novum - Jones cytuje orzeczenie sądowe pochodzące z 1869 r. (sic!), na jego tle wskazując, że ,jedną z istotnych przyczyn bałaganu, w jakim się znajdujemy, jest zwyczaj wykładania przez sądy ustawodawstwa podatkowego jako sprawy słów (as a matter of words)"39.

Kontrpropozycja zakłada z kolei większą swobodę interpretatora, w tym w ramach wykładni operatywnej przepisów, a także — w pewnym sensie — podział pracy prawotwórczej. Odpowiedzialnością tą dzielą się twórcy tekstu prawnego (parlament, $\mathrm{w}$ istocie wraz $\mathrm{z}$ ministerstwem finansów, jako rzeczywistym projektodawcą ogromnej większości przepisów podatkowych) oraz organy i sądy stosujące prawo (poddające kontroli jego stosowanie) ${ }^{40}$.

\section{7. (NIE)PEWNOŚĆ PRAWA}

Należy rozważyć, czy postulowany model legislacji nie zagraża pewności prawa podatkowego. Pewność prawa stanowi bowiem niezaprzeczalnie jedną z podstawowych jego wartości, domagającą się realizacji przy tworzeniu i stosowaniu prawa.

Przede wszystkim obecny stan rzeczy jest pod tym względem dość powszechnie uznawany za niezadowalający. Dlatego zmiana sposobu działania, nawet jeśli miałaby być traktowana w kategoriach eksperymentu, jest godna rozważenia. De-

38 Co ciekawe (i na co zwraca uwagę J.A. Jones), w Wielkiej Brytanii sądy sięgają po wykładnię celowościową, a mimo to parlament trwa przy praktyce nadawania przepisom podatkowym postaci szczegółowej i złożonej. Można to wyjaśnić bezwładem społecznej konwencji.

39 J.A. Jones, op. cit., s. 70.

40 A także - choć w mniejszym stopniu - prawnicy doradzający klientom, dziennikarze piszący o prawie itd. — wszyscy znaczący uczestnicy wspólnoty interpretacyjnej. 
ficyt pewności prawa, jakim dotknięte jest prawo podatkowe, świadczy o słuszności tezy, że „szczegółowość i pewność niekoniecznie idą w parze”41. Skoro dotychczasowe wysiłki, mimo mnożenia przepisów prawa, nie doprowadziły do satysfakcjonującego rezultatu, warto przetestować strategię różniącą się od stosowanej dotychczas.

Oparcie regulacji prawnej na zasadach, jednocześnie określających i wyrażających założenia konstrukcyjne ustawy podatkowej, pozwoli na jej lepsze rozumienie i da wyższą przewidywalność aktów stosowania prawa. Dająca się zidentyfikować logika ustawy, jako opartej na zasadach, umożliwi skuteczne przewidywanie wyniku postępowania podatkowego w stopniu wyższym niż wielość kalejdoskopowych reguł nieukładających się w żaden spójny obraz. W tym ostatnim wypadku wewnętrzna celowość ustawy zostaje zamącona i przesłonięta wielosłowiem, jej odtworzenie wymaga dużego natężenia wysiłków interpretacyjnych o charakterze racjonalnej rekonstrukcji, a tym samym wynik owego procesu jest chimeryczny.

Godzi się w tym miejscu wspomnieć o zagrożeniach dla praw podatnika związanych z subiektywizmem i tendencyjnością organów podatkowych. Zagrożenia te - choć realne - w mojej ocenie nie wiążą się z przyjęciem określonej techniki legislacyjnej i nie pogłębiają się z powodu jej przyjęcia. Ich źródłem jest występowanie tych organów w podwójnej roli: zarazem wierzyciela podatkowego oraz gospodarza postępowania podatkowego ${ }^{42}$. Ograniczenie tych zagrożeń wymagałoby reorganizacji ustrojowej aparatu podatkowego - wyodrębnienia organizacyjnego organów podatkowych z pionu ministerstwa finansów i nadania im organizacyjnej autonomii. Dyskusję tych i innych zabezpieczeń proceduralno-ustrojowych, jakie powinny towarzyszyć wdrożeniu modelu legislacji podatkowej opartej na zasadach i regułach, trzeba odłożyć do odrębnego opracowania.

\section{UNIKANIE OPODATKOWANIA}

Technika legislacji ogólnej pozwoli na zagwarantowanie pewności prawa, ograniczając jednocześnie okazje do nadużyć. W polu prawa podatkowego nadużycia te przyjmują postać tzw. unikania opodatkowania. Najprostsza jego definicja (która zarazem jest dla obecnych potrzeb dostatecznie ścisła pod względem rzeczowym) głosi, że unikanie opodatkowania to działanie zgodne z „literą” prawa, a niezgodne z jego „duchem” (celem, ratio legis). Unikanie opodatkowania (nadużycie prawa podatkowego) polega na eksploatowaniu formalizmu prawa podatkowego, z jego uszczegółowieniem, zniszczoną warstwą językową, tabu in-

41 J.A. Jones, op. cit., s. 65.

42 Organ podatkowy jest ,zarówno podmiotem prowadzącym postępowanie, jak i podmiotem stosunku materialnoprawnego" (R. Mastalski, Prawo podatkowe, Warszawa 2004, s. 267). 
terpretacyjnymi związanymi z deklarowanym prymatem wykładni językowej ${ }^{43}$. Metaforycznie rzecz ujmując, unikający opodatkowania wyzyskują ,prześwity” między poszczególnymi regułami, w ich językowej nieścisłości i nadmiernej komplikacji (przy swoistym „poszarpaniu” ich tkanki, pozostawiającym liczne luki), a także badają sfery „szarości” na obrzeżach owych reguł — po to, by w strefie nieuregulowanej, a przez to nieobciążonej podatkiem, umieścić własne działania gospodarcze.

Jak — za D. McBarnet i C. Whelanem ${ }^{44}$ — pisze J. Braithwaite, ,szwedzki stół reguł wytwarza kulturę pisania prawa polegającą na zabawie $\mathrm{w} »$ kotka i myszkę« - kulturę zamykania luk prawnych i ich ponownego otwierania przez $» k$ reatywne « przestrzeganie prawa (creative compliance)"45. Pomysłowe nadużycia prawa wymuszają kolejne interwencje legislacyjne, polegające na kreowaniu nowych reguł i dalszej komplikacji stanu normatywnego, co z kolei inspiruje do dalszych nadużyć. W nazbyt złożonym systemie o nieczytelnej logice każda nowa reguła prawna jest narażona na ryzyko nadużyć. Materializacja tego ryzyka zależy od upływu czasu i możliwych do osiągnięcia oszczędności podatkowych (im dłuższy czas i wyższe oszczędności, tym większe prawdopodobieństwo, że ryzyko się ziści).

Zjawiskiem powszechnie już rozpoznanym jest fakt, że komplikacja ta działa ostatecznie na niekorzyść ogółu uczciwych podatników, a jednocześnie przed podatnikami nieuczciwymi (angażującymi się w unikanie opodatkowania) otwiera wciąż nowe możliwości nadużyć ${ }^{46}$. Tworzy zatem „strukturalnie nieegalitarną formę niepewności" ${ }^{47}$.

Ustanowienie zasad prawnych przerywa to błędne koło, a raczej nakręcającą się wciąż spiralę działań. Regulacja oparta na zasadach i regułach redukuje ryzyko nadużyć dzięki temu, że jest ona bardziej „gładka”, jednorodna — nie zawiera wspomnianych prześwitów i luk. Braki warstwy językowej reguł mogą bowiem zostać wyrównane przy pomocy zasad ${ }^{48}$. Ponadto jedną z zasad (nie reguł) opo-

43 Por. D. McBarnet, C. Whelan, op. cit., s. 848-873. Autorzy opisują przeszkody i „prądy przeciwne”, na jakie napotyka trend ,antyformalistyczny” (w który wpisują się także postulaty zgłaszane w niniejszym artykule). Powodują one ponowny dryf od zasad (ogólnych standardów) ku regułom. Zob. też R. Prebble, J. Prebble, Does the use of general anti-avoidance rules to combat tax avoidance breach principles of the rule of law?, „Victoria University of Wellington Legal Research Papers” 2012, nr 8, s. 21-45.

44 D. McBarnet, C. Whelan, Creative accounting and the Cross-eyed Javelin Thrower, Wiley 1999, s. 28 (cyt. za: J. Braithwaite).

45 J. Braithwaite, op. cit., s. 6.

46 Ze względu na zakres tematyczny tego tekstu nie argumentuję na rzecz tezy, że unikanie opodatkowania jest zjawiskiem negatywnym; tezę tę w tekście głównym zakładam.

47 J. Braithwaite, op. cit., s. 6-9.

48 Elastyczność prawa, będąca wynikiem ogólności i dobrze uchwytnej wewnętrznej logiki tekstu prawnego, pozwala też na osiągnięcie adekwatności prawa wobec stosunków gospodarczych (por. P. Borszowski, op. cit., s. 386). Także dlatego model legislacji opartej na zasadach i regułach stwarza lepsze od dotychczasowego warunki zwalczania unikania opodatkowania. 
datkowania powinna stać się klauzula ogólna przeciwko unikaniu opodatkowania, w stosowny — a zatem ogólny (niekazuistyczny) sposób ${ }^{49}$ — wyrażona w ustawie podatkowej ${ }^{50}$.

\section{REALNOŚĆ PROPOZYCJI; DOŚWIADCZENIA ZAGRANICZNE}

Problematyczne może wydawać się to, czy postulowany model legislacji podatkowej jest osiągalny: czy sformułowane wyżej postulaty można urzeczywistnić - wprowadzić w życie. Czy zawsze można zidentyfikować zasady prawne rządzące opodatkowaniem danym podatkiem?

Źródło wątpliwości jest związane z wymogiem, by zasady, choć na płaszczyźnie językowej sformułowane w sposób ogólny, to jednak pojęciowo były dobrze określone. Istotne zastrzeżenia w tym względzie dotyczą podatku dochodowego i wspomnianej już cechy jego „ektopiczności” ${ }^{51}$. Prawne, a nawet (w porządku logicznym wcześniejsze od niego) ekonomiczne pojęcie dochodu nie wydają się dobrze skonstruowane; są one intelektualnie trudno uchwytne, rozmyte, niedookreślone. To właśnie rodzi pytanie o możliwość identyfikacji zasad opodatkowania podatkiem dochodowym.

Szczegółowa analiza tego zagadnienia wykracza poza ramy niniejszego tekstu. W konsekwencji pytanie to wypada pozostawić bez odpowiedzi. Trzeba jednak stwierdzić, że ewentualne przesądzenie o braku możliwości oparcia regulacji tego podatku na zasadach powinno prowadzić do wniosku o konieczności nie pozostania przy dotychczasowym modelu legislacji, a odstąpienia od nakładania tego podatku $\mathrm{w}$ ogóle ${ }^{52}$. Przesądzenie to oznaczałby bowiem, że $\mathrm{w}$ istocie nie wiemy, co i jak chcemy opodatkować, a także że nieusuwalne jest źródło nadużyć

49 Klauzula wprowadzona ustawą z dnia 13 maja 2016 r., Dz.U. poz. 846 (art. 119a-119f Ustawy z dnia 29 sierpnia 1997 r. — Ordynacja podatkowa, tekst jedn. Dz.U. 2015 poz. 613 ze zm., nie jest jednak zasadą prawną, lecz regułą — z czego można uczynić jej zarzut (przeciwstawny zresztą stawianym typowo zarzutom niedostatecznej określoności).

${ }^{50}$ Postulat ten został sformułowany m.in. w: J. Freedman, Defining taxpayer responsibility: In support of a general anti-avoidance principle, „British Tax Review” 2004, nr 4, s. 332-357.

51 Zob. J. Prebble, Should tax legislation..., s. 112-123. Autor twierdzi, że „przepisy o podatku dochodowym nie są oparte na właściwej (sound) zasadzie a priori”' (s. 122). Nie jest jasne, czy uważa, że nie tylko „nie są”, lecz także „nie mogą” one być oparte na takiej zasadzie, a jeśli tak, to dlaczego. Samo zjawisko ektopii nie wyjaśnia dostatecznie tej niemożności.

52 Zastąpienie podatku dochodowego podatkiem „od działalności i sprzedaży” w danym państwie rozważa się m.in. w Wielkiej Brytanii. Por. też propozycję fundamentalnej rekonstrukcji zasad podatku dochodowego w oparciu o regułę opodatkowania w miejscu (państwie) rezydencji nabywcy towarów lub usług (zamiast dotychczasowych reguł rezydencji i źródła) w: M. Devereux, R. de la Feria, Designing and implementing a destination-based corporate tax, May 2014, Oxford University Centre for Business Taxation, Working Paper Series, WP 14/07, http://eureka.sbs.ox.ac. uk/5081/1/WP1407.pdf. 
w tym podatku - które i tak w coraz większym stopniu redukują pochodzące z niego wpływy budżetowe.

Warto odnotować, że analiza doświadczeń zagranicznych nie prowadzi do jednoznacznych wniosków odnośnie do szans powodzenia „legislacji podatkowej opartej na zasadach" (principle-based tax legislation). W literaturze napotkać bowiem można zniuansowane i w pewnym stopniu zróżnicowane oceny tych doświadczeń. Graeme S. Cooper opisuje reformy legislacyjne przeprowadzone w Australii, zmierzające do oparcia pewnych części (obszarów) ustawodawstwa podatkowego na zasadach, i ocenia je jako nieudane ${ }^{53}$. Ten sam autor wskazuje jednak, że przyczyną niepowodzenia mógł być brak „właściwej wizji (vision) podstawowej zasady” i „sztuczność” przyjętej koncepcji przedmiotów, które miały podlegać opodatkowaniu ${ }^{54}$. W tym samym duchu, lecz bardziej zdecydowanie, a zarazem bardziej optymistycznie, wypowiada się J. Freedman. Autorka ta dość krytycznie ocenia efekty brytyjskiego projektu, tzw. principles-based legislation. Wskazuje wszakże istotne uwarunkowania tego eksperymentu: dotyczył on (zarówno w Wielkiej Brytanii, jak i w Australii) opodatkowania instrumentów finansowych, a zatem przedmiotów opodatkowania odległych od codziennego doświadczenia, „sztucznie konstruowanych” i „nieintuicyjnych”55. Freedman argumentuje też, że regulacja została oparta na źle skonstruowanych zasadach, a sam eksperyment był fragmentaryczny, zakresowo zbyt wąski, nieuwzględniający całokształtu regulacji podatkowej ${ }^{56}$.

Doświadczenia te wskazują na trudność przedsięwzięcia, jakim jest przebudowa ustaw podatkowych w celu oparcia regulacji na zasadach. Nie dowodzą jednak braku możliwości osiągnięcia w tym względzie sukcesu. Wobec tego nie można a priori przekreślać szans powodzenia podobnego projektu w warunkach polskich.

\section{UWAGI KOŃCOWE}

Główne ustalenia tego artykułu są następujące:

- powszechnie stosowana technika legislacji podatkowej naznaczona jest dążeniem do maksymalnej precyzji (ścisłości) tekstu prawnego, co jednak nie sprzyja komunikatywności (jasności) tego tekstu, a w konsekwencji — pewności prawa, jednocześnie otwierając regulację na nadużycia (unikanie opodatkowania);

— przyczyny przyjęcia „modelu prawodawczego konkretu” są liczne; ważną ich grupę stanowią przekonania na temat natury prawa podatkowego, w tym jego ingerencyjności;

53 Zasady były z czasem uzupełniane sukcesywnie komplikowanymi regułami, aż w końcu odstępowano od rozróżnienia na zasady i reguły.

54 G.S. Cooper, op. cit., s. 347-360.

55 J. Freedman, Improving..., s. 731.

56 Ibidem, s. 735-736. 
— przekonania te nie są jednak dobrą racją dla obranego w prawie podatkowym modelu legislacyjnego, o czym świadczy przykład prawa karnego - ingerencyjnego par excellence, a jednak budowanego przy pomocy dyrektyw sformułowanych ogólnie i operujących zwrotami niedookreślonymi i klauzulami generalnymi;

- postulowana alternatywą wobec dotychczasowego modelu jest oparcie tekstu ustaw podatkowych jednocześnie na ogólnych zasadach (określających konstrukcję podatku) oraz regułach prawnych (określających skutki podatkowoprawne transakcji typowych), przy jednoczesnym przyzwoleniu na większą swobodę interpretacyjną $\mathrm{w}$ ramach procesu stosowania prawa;

— wolno sądzić, że postulowany model tworzenia i stosowania prawa podatkowego nie zniszczy pewności prawa, zarazem ograniczając nadużycia; wobec powszechnie krytykowanego status quo warto poddać go testowi praktyki.

\section{PRINCIPLES AND RULES. LEGAL CERTAINTY IN TAX LAW AND CUL-DE-SAC OF CONCRETENESS}

\section{Summary}

The purpose of the article is to discuss and critically evaluate the legislative model adopted in lawmaking of the tax law. The model is premised upon the strategy of striving towards the maximal available precision (determinacy) of legal norms through constructing the multitude of detailed (prescriptive) legal rules. In practice this legislative style is combined with, and goes hand in hand with textualism: a position advocating adherence to the linguistic directives (arguments) of legal interpretation. As a result, the communicativeness and clarity of tax law are impaired.

In the article an alternative model is postulated, entailing that tax law is based not only on legal rules but also, if not primarily, on legal principles (in case of conflicts prevailing over rules), and that in drafting legal provisions open-ended and general formulas (expressions) are used. Contrary to what is commonly believed, this legislative model and the corresponding drafting technique are not detrimental to legal certainty. It is argued that the opposite is true: they can serve the purpose of legal certainty better that the current model does, while at the same time improving the effectiveness of efforts to combat tax avoidance. 